\title{
Development of a 3-D hydro-geochemical model to assess water quality and acidification risk in the Murray Lower Lakes, South Australia
}

\author{
$\underline{\text { M.R. Hipsey }}^{\text {a,b }}$, S.U. Salmon ${ }^{\text {a }}$, L.M. Mosley ${ }^{\mathrm{c}}$, L. Barnett ${ }^{\mathrm{d}}$ and J. Frizenschaf ${ }^{\mathrm{d}}$ \\ ${ }^{a}$ School of Earth and Environment, The University of Western Australia, \\ 35 Stirling Highway, Crawley WA 6009, Australia. \\ ${ }^{b}$ Centre for Ecohydrology, School of Environment Systems Engineering, The University of Western \\ Australia, 35 Stirling Hwy, Crawley WA 6009, Australia \\ ${ }^{c}$ Environment Protection Authority, Murraylands Office, GPO Box 2607, Adelaide, SA 5001, Australia \\ ${ }^{d}$ Department of Environment and Natural Resources, GPO Box 1047, Adelaide SA 5001, Australia \\ ${ }^{e}$ South Australian Water Corporation, 250 Tarndanyangga Victoria Square, Adelaide SA 5000, Australia
}

Email: matt.hipsey@uwa.edu.au

\begin{abstract}
Widespread decreases in rainfall throughout the Murray-Darling Basin, superimposed on the significant allocation of water for irrigation, resulted in an order of magnitude reduction in flow over the period from 2004-2009. This resulted in a dramatic shift in flow regimes and water quality in the lower River Murray, and in particular substantial decline in the water level of the Lower Lakes at the base of the Murray, which are disconnected from the ocean by barrages to prevent salt-water intrusion up the river. A consequence of the declining water level in the Lower Lakes was the exposure of pyrite-bearing lake sediments, leading to an increased risk of acid sulfate soil impacts. The potential for large-scale acid generation in sediments created the potential for acid and dissolved metal release to degrade water quality, with associated ramifications for biodiversity.
\end{abstract}

Here we document a coupled model system for simulating lake water quality that adopted an existing threedimensional (3-D) lake hydrodynamic-biogeochemical model (ELCOM-CAEDYM) and was coupled with a novel soil hydro-geochemical model suited to simulation of acid sulfate soils. The soil hydro-geochemical model required a simplified vertical representation to allow computationally efficient application across a spatially heterogeneous domain and for dynamic linking with the 3-D lake hydrodynamic-biogeochemical model, however, the vertical structure of acid sulfate soils can not be overly simplified due to the importance of the unsaturated zone soil moisture profiles and the variability of pyrite with depth for acidity dynamics. A separate 2-D sensitivity analysis using the full Richard's equation solution was used to identify dominant system dynamics and parameterise the simplified vertical processes in the soil model, as well as horizontal connection to the lake. The coupled soil-lake model was validated against a range of surface water quality data collected during 2009. Several acidification events that occurred around the perimeter of the lake system during this period were well captured by the model, allowing us to identify the key processes controlling the generation and mobilisation of acidity.

The model showed that the dominant flux of the acidity occurs following pulses of rain that collect acidity from surficial regions of the exposed sediment and drive lateral flow to the lake edge. Acidification of groundwater and subsequent baseflow to the lake was a much less significant delivery mechanism, and in this case the diffusive flux of acidity following reflooding was also low on average. The model demonstrated the large spatial variability in the manifestations of acid sulfate soils, and the potential for 'hotspot' locations that require priority management. The validated model has subsequently been used to estimate the range of timeframes for large-scale lake acidification through forecast scenarios, in order to allow for planning mitigation strategies and to highlight targeted areas for further field and laboratory research to help reduce model uncertainty.

Keywords: biogeochemistry, hydrodynamics, hydrology, water quality, acid sulfate soils, drought, Lake Alexandrina 


\section{INTRODUCTION}

Widespread decreases in rainfall throughout the Murray-Darling Basin from 2004-2009 resulted in an order of magnitude reduction in flow over the past decade. In particular, this resulted in a dramatic shift in flow regimes and biogeochemical cycling of the Lower River Murray, including significant changes to water quality properties such as salinity, nutrients, algae and turbidity (Hipsey et al., 2010). Below Wellington, the river enters Lake Alexandrina, which in turn is connected to Lake Albert, collectively referred to as the Lower Lakes. The lakes have been separated from the Coorong, an estuarine-hypersaline lagoon, by barrages since the 1930s, and are listed under the Ramsar Wetland Convention owing to their high natural diversity.

The unprecedented rate of water level decline in the lakes during 2008-2009 generated several water quality related management concerns. Of particular concern was the exposure of pyrite-bearing lake sediments and the increased risk from acid sulfate soil impacts. Acidification of water courses can occur when reduced sulfides are exposed to oxygen (Ward et al., 2004). While high concentrations of sulfides have been reported to occur in inland water systems (Baldwin et al., 2007), they are typically associated with coastal areas, since high sulfate concentrations in seawater fuel sulfate reduction in anoxic sediments and promote the subsequent formation of sulfidic materials such as pyrite. Surface waters become at risk of acidification when pyritic material is disturbed and oxidised, for example, as a result of altered drainage or dredging/reclamation activities, and the resulting acidity is transported into the surface waterbody. While the Lower Lakes are mainly fresh and no drainage actions have occurred to trigger the oxidation process, they have however been exposed to high sulfate concentrations that has led to a build up of pyrite and the oxidation process has occurred due to the relatively rapid (and unprecedented) rate of water level decline exposing perimeter regions of the lake sediment to the atmosphere (Fitzpatrick et al., 2009).

This led to several management options being implemented, including disconnection of Lake Alexandrina, Lake Albert and the Finniss/Currency region (from west of Clayton to Goolwa), large-scale limestone additions to acidified areas, and reintroduction of organic matter to exposed sediments to enhance alkalinity generation. Other options considered also included the potential for seawater introduction to stabilise water levels (Hipsey et al., 2011). However, in the winter of 2010 increased regional rainfall and flow rapidly raised the lake levels, which led to a significant recovery in most lake water quality properties.

In this paper we report on the development of a spatially resolved hydro-geochemical model of the system to provide a quantitative understanding of ecosystem processes and services during this period of rapid environmental change. By further understanding the complex response pathways of the lake ecosystem to change, our aim has been to develop a tool to support improved decision-making and management outcomes.

\section{MODEL APPROACH}

To the best of our knowledge there was no suitable model platform able to resolve the interaction of lake hydrodynamics and biogeochemistry with the hydrology and biogeochemistry of the surrounding (riparian) acid sulfate soil material. We therefore developed a model system by linking an existing 3-D lake hydrodynamic-water quality model (ELCOM-CAEDYM, developed at the Centre for Water Research, University of Western Australia) with a novel Acid Sulfate Soil (ASS) model able to resolve the basic hydrology and biogeochemistry of the exposed soil material. In summary, the model includes:

- 3-D hydrodynamics, including prediction of circulation patterns, inflows (including pumping and seawater entrance), wetting and drying, temperature, salinity, surface thermodynamics and evaporation;

- 2-D spatially variable specification of soil texture and geochemistry, which allows for heterogeneity in soil hydraulic properties, pyrite content, and acid neutralising capacity at high-resolution;

- Vertically resolved pyrite oxidation reaction kinetics in exposed cells based on dynamically predicted moisture content profiles, and subsequent neutralisation kinetics;

- Estimation of acidity flux to the surface water following re-wetting of exposed cells during flooding, and also from overland flow and lateral seepage processes;

- Buffering of water $\mathrm{pH}$ by lake and river alkalinity and internal lake biogeochemical dynamics, including approximation of alkalinity generation by organic matter decomposition in submerged sediments.

A detailed description of the model components and mathematical basis is available from Hipsey et al. (2011), and a brief overview is presented here. The model is parameterised based on available data and results from strategic experimental work (eg. Fitzpatrick et al., 2009; Earth Systems, 2010). Whilst the model has been applied across the full lake system, here we report specifically on its application and validation to the "Currency-Creek region", from Goolwa Barrage to Clayton in the south-west of Lake Alexandrina, and identify the dominant controls on the acidification process and water quality response. This region was of particular interest due to acidification of large expanses during 2009 (Fitzpatrick et al. 2009). 


\subsection{Lake Hydrodynamics}

The 3-D Estuary, Lake and Coastal Ocean Model (ELCOM) is used to predict the velocity, temperature and salinity distribution, including stratification, in response to environmental forcing. Numerous published studies have validated the model across sites ranging from large lakes and reservoirs, to estuaries and coastal lagoons, including in the Lower Murray River and the Lower Lakes (see Hipsey et al., 2010).

\subsection{Lake Biogeochemistry}

The Computational Aquatic Ecosystem Dynamics Model (CAEDYM) is used to simulate numerous biogeochemical parameters including: inorganic particles, oxygen, organic and inorganic nutrients $(\mathrm{C}, \mathrm{N}, \mathrm{P}$ and $\mathrm{Si}$ ), and three phytoplankton groups. Additionally, here we include a geochemistry module able to solve the equilibrium speciation of geochemical components (Al, $\mathrm{Ca}, \mathrm{Mg}, \mathrm{Na}, \mathrm{K}, \mathrm{Fe}(\mathrm{II}), \mathrm{Fe}(\mathrm{III}), \mathrm{Mn}(\mathrm{II}), \mathrm{SiO}_{2}, \mathrm{Cl}$, $\mathrm{DIC}, \mathrm{SO}_{4}, \mathrm{PO}_{4}, \mathrm{NO}_{3}$, and $\left.\mathrm{NH}_{4}\right)$, including precipitation/dissolution of mineral phases $\left(\mathrm{Fe}(\mathrm{OH})_{3}, \mathrm{Al}(\mathrm{OH})_{3}\right.$, $\mathrm{MnO}_{2}$ and $\left.\mathrm{CaCO}_{3}\right)$. Kinetic processes are also configured such as microbially-mediated redox transformations. The geochemical model has been tested from mine lakes impacted by acid mine drainage (Oldham et al., 2009) to $\mathrm{pH}$ neutral waters including the lower Murray River (Hipsey et al., 2010).

\subsection{Riparian Zone Hydrology}

The key factor in determining the generation and mobilisation of acidity to the lake is the hydrology of the zone surrounding the lake perimeter; these dynamics control the amount of oxygen that can penetrate into the soil and the amount of lateral flow able to transport acidity to the lake. The soil hydrology model implemented here operates on each dry cell (ie. no standing water above it) within the grid and is based on a conceptual 2-layer storage-capacitance model able to resolve the unsaturated zone thickness and moisture content, and the saturated zone thickness and seepage flux (see inset in Fig. 1). The model is a modified version of that presented in Farmer et al. (2003) and is driven at the surface by daily rainfall and evaporation fluxes. Saturation and infiltration excess water from each cell is considered to 'pond' or contribute to finescale through-flow processes above the water-table and this water $\left(Q_{s e}\right)$ is routed to the closest lake cell based on the local topographic relief. Vertical percolation to the saturated zone occurs for stored water above the field capacity, and the water table in each cell changes in response to this infiltration amount, and subsequent evaporation and lateral flow (seepage) losses. A simple parameterisation is used to estimate seepage, and a separate 2-D cross-section analysis using a full Richard's equation solution (HYDRUS-2D) was performed to simplify vertical and horizontal processes to storage-capacitance relationship of the form $Q_{s s}=\left[S(t) / S_{\text {max }}\right]^{\beta}$, where $S_{\max }$ is the cells maximum storage capacity. The processes are dependent on the soil texture and the model allows for input of different soil types in each cell of the model grid.

\subsection{Soil Biogeochemistry (Acid Sulfate Soils)}

The pyrite oxidation process in exposed sulfidic sediments is rate limited and dependent on numerous factors

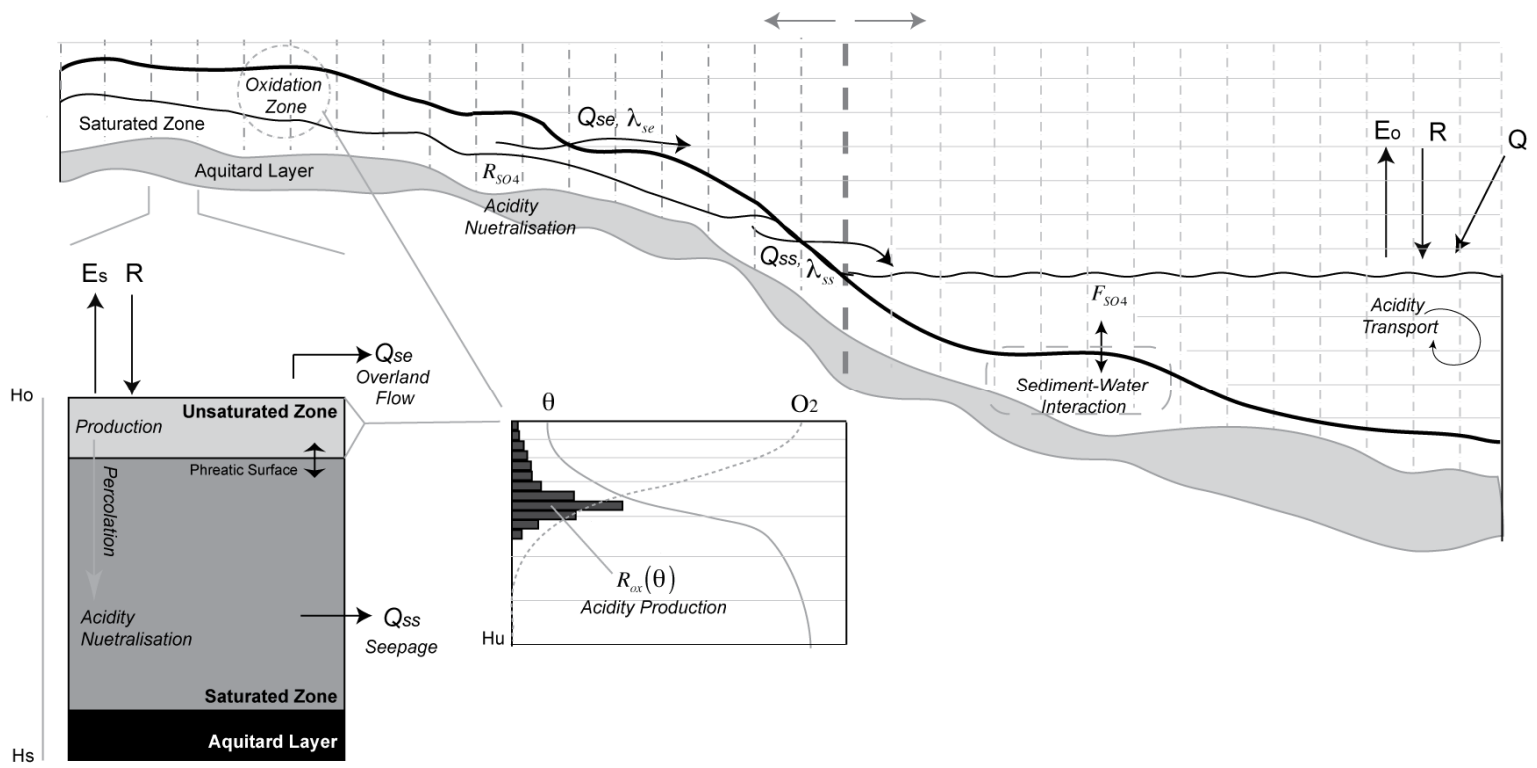

Figure 1. Schematic of model of acid generation and transport processes. Notation: $\mathrm{E}=$ evaporation; $\mathrm{R}=$ rainfall; $\mathrm{Q}=$ general inflows entering the lake; $\theta=$ soil moisture; $\mathrm{O}_{2}=$ oxygen concentration; $\mathrm{Q}_{\mathrm{se}}=$ saturation excess flow; $\mathrm{Q}_{\mathrm{ss}}=$ seepage flow; $\mathrm{R}_{\mathrm{SO} 4}=$ acidity consumption via $\mathrm{SO}_{4}$ reduction; $\mathrm{R}_{\mathrm{ox}}=$ pyrite oxidation; $\mathrm{F}_{\mathrm{SO} 4}=$ acidity consumption by $\mathrm{SO}_{4}$ reduction in lake sediments; $\lambda_{r w}=$ flux of acidity from acidified sediment following rewetting; $\mathrm{Hs}=$ height of soil column; $\mathrm{Ho}=$ height of soil surface; $\mathrm{Hu}=$ height of water table. 
such as the chemical kinetics, biotic factors, and in particular, the rate of oxygen diffusion into the soil profile (Ward et al., 2004; Earth Systems, 2010). Once sulfuric material is generated and acidity is liberated into pore-waters, delivery of the leachate to the lake water is not immediate and depends on suitable loading mechanisms, such as flushing of the soil profile in response to rainfall events (Section 2.3) or diffusive fluxes from oxidised sediment into the standing water upon re-wetting of the sediment. To capture the response to shifting water levels, the model allows for these important controls on acidity generation and transport and predicts the loading fluxes to the lake (Fig. 1), based on three main components:

1) the Potential Acidity (PASS, mol H $\mathrm{kg}^{-1}$ ), $\chi$, is the 'reservoir' of sulfides exposed to oxygen;

2) the Available Acidity (AASS, mol H $\mathrm{kg}^{-1}$ ), $\varphi$ is the amount of acidity available at any given time within a soil/sediment unit, and subject to neutralisation (based on consumption of the local Acid Neutralising Capacity (ANC) and alkalinity production through $\mathrm{SO}_{4}$ reduction) and transport processes;

3) the Acidity Flux ( $\mathrm{mol} \mathrm{H}^{+} \mathrm{d}^{-1}$ ), $\lambda$, which is the rate of transfer of the acidity from the soil to the surface water $\left(\lambda_{s e}+\lambda_{s s}\right)$ and this is based on the soil hydrological model, or prescribed diffusive flux rates if a cell becomes inundated $\left(\lambda_{r w}\right)$.

\section{MODEL SETUP}

Bathymetric information was interpolated onto a $100 \times 100 \mathrm{~m}$ grid covering the area from Goolwa to Clayton (Fig. 2) with a variable vertical grid resolution in the water, ranging from $0.2 \mathrm{~m}$ for the top $1.6 \mathrm{~m}$ and then gradually increasing to a maximum of $0.5 \mathrm{~m}$ at the bottom of the lake bed. Based on numerical stability limitations a time-step of 200s was adopted to ensure the Courant-FriedrichLowry (CFL) condition was $<0.7$.

The model has several boundary condition (BC) locations configured (Fig. 2), including the Finniss River inflow, the Currency Crk inflow and Goolwa barrage saline seepage. Additionally, on the eastern most edge of the domain (approximately $1 \mathrm{~km}$ east of Clayton), the model is configured to have an open boundary connecting it to the main body of

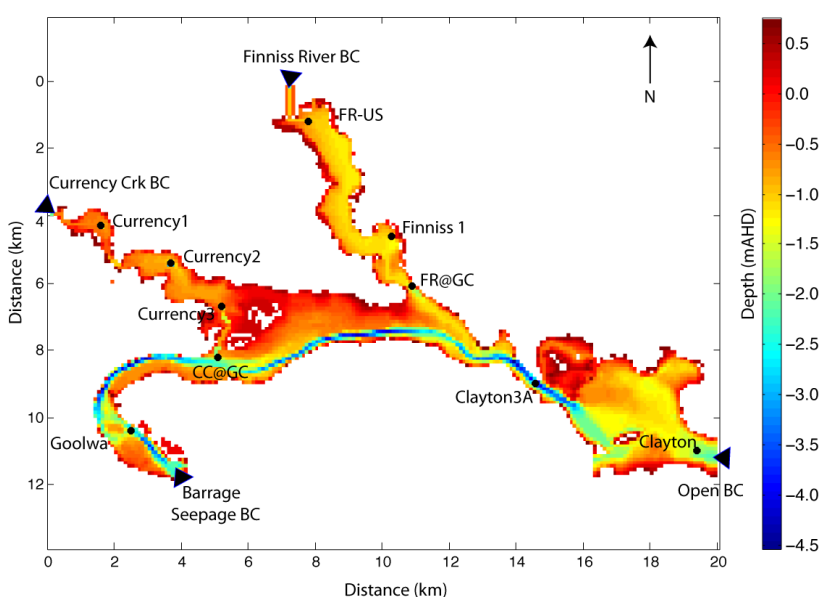

Figure 2. Model bathymetry for $100 \times 100 \mathrm{~m}$ Currency Crk and Finniss River domain, showing boundary forcing locations, the open boundary connection point with the main Lake Alexandrina domain, and the main sampling locations $(\bullet)$ used to validate the model.

Lake Alexandrina. At this point the height is specified based on water level data, and physical, geochemical and biological water attributes are specified from a larger lake domain model simulation (see Hipsey et al. 2011), thereby nesting this high-resolution region within a larger Lake Alexandrina simulation. Flow data from the Currency and Finniss tributaries is estimated from upstream gauge data, and available grab sample data for water quality attributes was interpolated onto a daily timestep for input into the model.

In addition to wind and inflow forcing, the model was configured to simulate surface thermodynamics, and correction for non-neutral atmospheric stability was also applied. Meteorological data (15min) from the Currency Crk weather station was used for rain, relative humidity, air-temperature, and wind speed and direction. Solar radiation data was obtained from Hindmarsh Valley (20km west of the site), and long-wave radiation was estimated from available net-radiation data also collected at this site by subtracting the shortwave component.

The simulations were configured to begin on 1 Jun 2008. Initial values for the water column variables were estimated from available physical and water quality data collected at that time from various stations across the site. The soil type classification (coarse sand, medium sand and clay), initial sulfide (PASS) and ANC concentrations were set at the beginning of the simulation for each cell (Fig. 3), based on CSIRO mapping data (Fitzpatrick et al., 2010) that was interpolated onto the $100 \times 100 \mathrm{~m}$ domain. In each cell, cells were set to have a maximum depth $\left(H_{s}\right)$ of up to $1.5 \mathrm{~m}$ to the aquitard layer and vertical profiles of ANC and PASS below the top $20 \mathrm{~cm}$ were then assigned based on an average profile of data collated from a range of sites across Lake Alexandrina (Earth Systems, 2010). Detailed justifications of model parameters for the soil hydrological processes and biogeochemical transformations are provided in Hipsey et al. (2011).

In September 2009 following acidification of the Currency tributary region, a flow regulator (earth bund) was installed across the channel near Clayton, and also one in Currency tributary. To account for the affect of 
this on the flows, the model was stopped at this point, and a subsequent simulation was started with these barriers implemented as levees, and initial conditions based on the ending conditions of the first simulation.

\section{MODEL VALIDATION}

\subsection{Validation Data and Approach}

A substantial quantity of water quality data has been collected including routine (ambient) monitoring and 'event-based' monitoring in high priority management areas displaying signs of acidification or poor water quality. Additionally, real-time sensor data is available for water level, salinity and $\mathrm{pH}$ from http://data.rivermurray.sa.gov.au, which together provides a substantial dataset to rigorously validate the model.

For the full lakes domain, the analysis includes 34 real-time monitoring sites (data at high frequency), and 340 regular or occasional monitoring locations (varying in frequency from once off to weekly/monthly). Within the focus region presented here, 6 DFW stations are present and $~ 50$ EPA sites (main sites are indicated on Fig. 2). The model has been assessed against this data for variables including salinity, temperature, turbidity, chlorophyll-a, nutrients (TN, $\mathrm{NO}_{3}, \mathrm{NH}_{4}, \mathrm{TP}$ $\left.\mathrm{PO}_{4}, \mathrm{SiO}_{2}\right), \mathrm{pH}$, alkalinity, major ions, and metals (including particulate and dissolved $\mathrm{Fe}$ and $\mathrm{Al}$ ). For brevity in this paper, some data from nearby sites are combined and only selected variables from key monitoring data is displayed to highlight key features (Fig. 4).

\subsection{Physico-Chemical and General Water Quality Conditions}

The water levels during the drawdown phase in 2008-2009 are accurately predicted, and the subsequent refilling following installation of the flow regulators in Sept 2009, however there is an over-prediction of water level in winter of 2010, most likely due to inaccuracies in estimated inflow volumes from Finniss River. The model predicted the disconnection of the upper and lower Currency tributary pools at approximately the right time, and the maintenance of connection in the Finniss tributary. Water temperatures were well predicted, and the model captured a notable horizontal gradient across the model domain and seasonal cycles of evapo-concentration and dilution in electrical conductivity. A very sharp salinity increase in the upper Currency tributary pool (during summer of 2008-09) is not seen in the model due to inflowing water from the inflowing boundary condition. Therefore, there is likely some error in applying the Currency flow measurements directly at the domain boundary (since they are measured upstream) and there is also potentially an appreciable groundwater contribution.

Patterns of dissolved oxygen, dissolved organic carbon, nutrients, chlorophyll-a and turbidity were all highly variable over the drawdown and refilling cycle, but the range was captured well by the model (not shown here). The major ion $\left(\mathrm{Ca}, \mathrm{Na}, \mathrm{Mg}, \mathrm{Cl}, \mathrm{SO}_{4}\right)$ concentrations in the main channel and tributaries were predicted in line with observations and in general followed the patterns of electrical conductivity and hence are not shown here. There was some under-prediction of these in the disconnected pools (eg. upstream Currency Crk and to a lesser extent Finniss River) during the sharp concentration increase over the early 2009 dry period. 
Hipsey et al., Hydro-geochemical model of surface water quality in Murray Lower Lakes

This could be due to errors in the predicted pool starting size and also the lack of groundwater contribution in the model, or errors associated with the inflow boundary specification of water quality attributes. There is also under-prediction in the winter of 2010, which is due to the over-prediction in the water level.

\subsection{Acidification Dynamics}

The acidity flux from the model is small until the first rains of 2009, at which point both the Currency Crk tributary pools go acidic, in May 2009 (Fig. 4). The model predicts the timing and extent of the acidity well. There are however some parts of the domain that are also predicted to experience short-lived acid pulses that are not observed. These are most likely due to erroneous specification of soil textural properties near the domain perimeter. The alkalinity (Fig. 4) shows a build up over the summer of 08/09, and a sharp drop during refilling in mid-2009, followed by a quick recovery and stabilisation upon refilling.

Sensitivity of key model parameters was conducted (not shown here) to understand the key processes that shape the degree and extent of lake water acidification. This analysis suggested that the soil hydrological processes were very important and in particular the rate of soil drying and the height of the capillary fringe, and also the vertical percolation rate of acidity in pore-water leachate following rainfall.

Whilst Fig. 4 shows the spatial variability, the model provides spatial integrations of key acidity pools and fluxes that demonstrate the system-scale production, neutralisation and transport pathways. An annual average budget of these key acidity fluxes and stores of acidity was compiled for the Sep 2008-Sep 2009 period to gain insights in to the dominant drivers of the acidification dynamics during the 2009 acidification event (Fig. 5). These sums indicate that the amount of available acidity in the unsaturated zone was around 60,000 tonnes of $\mathrm{H}_{2} \mathrm{SO}_{4}$ of which approximately 12 tonnes per day (averaged over the year) was transported to the lake. The key flux process appeared to be via shallow groundwater seepage (interflow) through the unsaturated zone following intense rainfall events, with only minor fluxes arising from the lateral movement of water within the saturated zone (-0.01 tonnes per day). This was approximately $22 \%$ of the acidity that was oxidised during the period and a further $30 \%$ of the oxidised material was neutralised by ANC or alkalinity produced via $\mathrm{SO}_{4}$ reduction. Diffusive fluxes from rewetting of acid soil were small ( 0.003 tonnes per day).
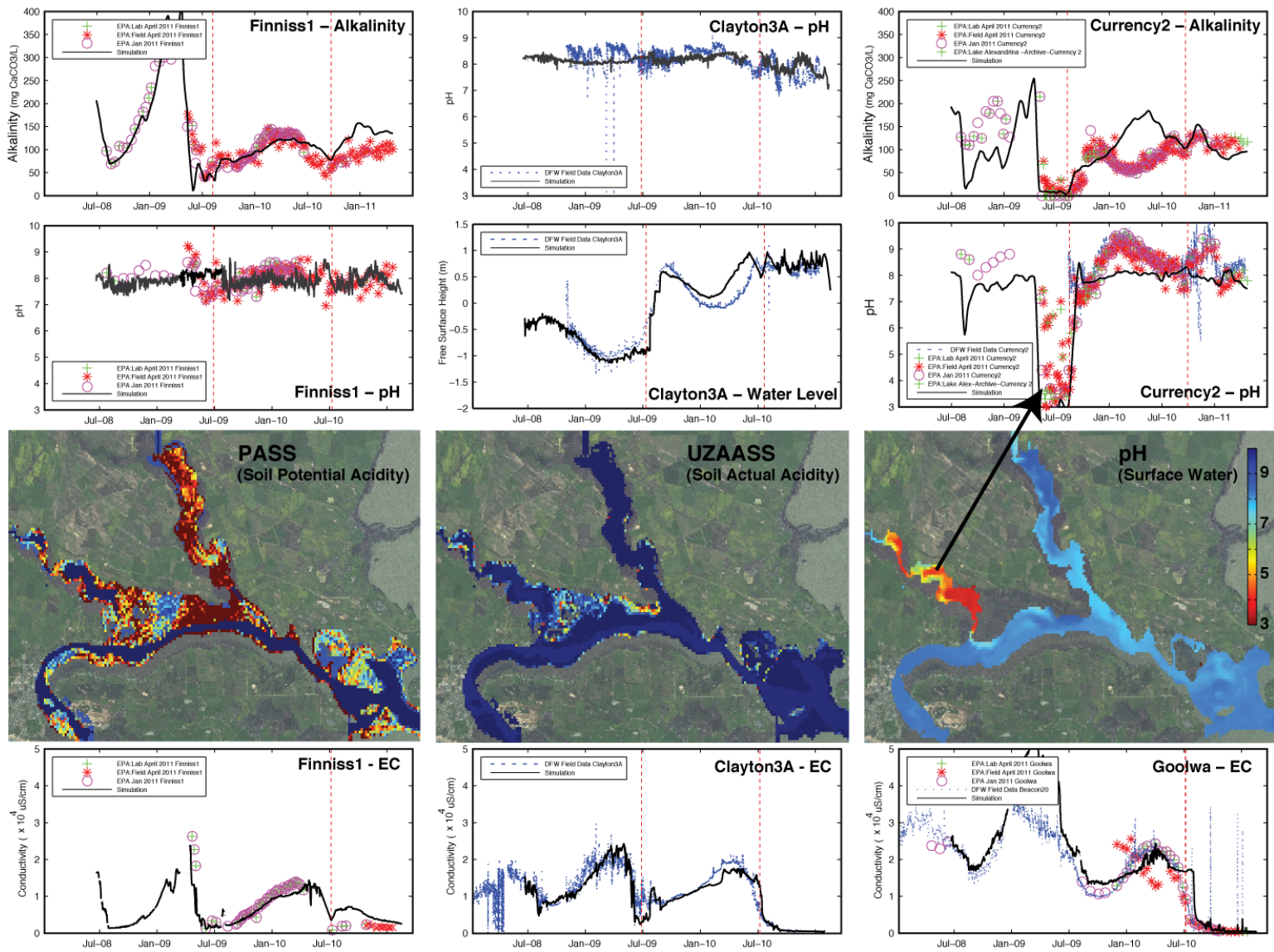

Figure 4. Spatial distribution of exposed PASS $(=\chi)$ and UZAASS $(=\varphi$ is the unsaturated zone) and water $\mathrm{pH}$ in July 2009, with associated validation plots of simulated water level, conductivity, alkalinity and $\mathrm{pH}$ at key

points. 


\section{CONCLUSIONS}

- The model presented here allows for the simulation of lake water quality as impacted by a spatially resolved acid sulfate soil model active in the dry cells of the numerical domain.

- The model is applied to Lake Alexandrina and validated against a large range of water quality monitoring data, and it accurately predicted an acidification event in the Currency Crk tributary region, and the subsequent water quality recovery following refill.

- Key dynamics show that the dominant flux of the acidity occurs following pulses of rain that collect acidity from surficial regions of the exposed sediment and drive lateral flow to the lake edge. Acidification of groundwater and subsequent baseflow to the lake was a much less significant delivery mechanism, and in this case the diffusive flux of acidity following reflooding was also low on average.

- The model is also used to demonstrate the large spatial variability in the manifestations of acid sulfate soils, and the potential for 'hotspot' locations that require priority management.

- The validated model has also been used to estimate the range of time-frames for large-scale lake acidification through forecast scenarios, in order to allow for planning mitigation strategies and to highlight targeted areas for further field and laboratory research to help reduce model uncertainty.

\section{ACKNOWLEDGMENTS}

We gratefully acknowledge funding from the Australian Government's Murray Futures program and the MDBA, the SA Water Corporation and SA Department of Environment and Natural Resources (DENR), and data from the SA Environmental Protection Agency (EPA) and SA Department for Water (DFW).

\section{REFERENCES}

Baldwin, S, Hall, K., Rees, G. and Richardson, A. (2007). Development of a protocol for recognizing sulfidic sediments (potential acid sulfate soils) in freshwater wetlands. Ecol. Manage. Restoration, 8(1): 56-60.

Earth Systems (2010). Quantification of acidity flux rates to the Lower Murray Lakes. Prepared by Earth Systems Consulting Pty. Ltd. for the SA Department of Environment and Natural Resources, Adelaide.

Farmer, D., Sivapalan, M. and Jothityangkoon, C. (2003). Climate, soil, and vegetation controls upon the variability of water balance in temperate and semiarid landscapes: Downward approach to water balance analysis. Water Resour. Res., 39(2): 1035-1056.

Fitzpatrick, R.W., Grealish, G., Chappell, A., Marvanek, S. and Shand, P. (2010). Spatial variability of subaqueous and terrestrial acid sulfate soils and their properties, for the Lower Lakes South Australia. Prepared by the Commonwealth Scientific and Industrial Research Organisation (CSIRO) Land and Water for the SA Department of Environment and Natural Resources, Adelaide. Available from DENR website.

Fitzpatrick, R.W., Grealish, G., Shand, P., Simpson, S.L., Merry, R.H. and Raven, M.D. (2009). Acid sulfate soil assessment in Finniss River, Currency Creek, Black Swamp and Goolwa Channel, South Australia. CSIRO Land and Water Science Report 26/09 Report for the Murray-Darling Basin Authority (MDBA).

Hipsey, M.R., Busch, B.D., Coletti, J.Z. and Salmon, S.U. (2011). Lower Lakes hydro-geochemical model development and assessment of acidification risks. University of Western Australia Technical Report prepared for South Australian Water Corporation, Adelaide. Available from the DENR website.

Hipsey, M.R., Salmon, S.U., Aldrige, K.T. and Brookes, J.D. (2010). Impact of hydro-climatological change and flow regulation on physical and biogeochemical dynamics of the Lower River Murray, Australia. Proc. 8th International Symposium on Ecohydraulics (ISE2010), September, 2010, Korea.

Oldham, C.E., Salmon, S.U., Hipsey, M.R. and Ivey, G.N. (2009). Modelling pit lake water quality: Coupling of lake stratification dynamics, lake ecology, aqueous geochemistry and sediment diagenesis. In: Castendyk, D.N. and Eary, L.E. [eds], Mine Pit Lakes: Characteristics, predictive modeling and sustainability, Acid Drainage Technology Initiative.

Ward, N.J., Sullivan, L.A. and Bush, R.T. (2004). Soil pH, oxygen availability, and the rate of sulfide oxidation in acid sulfate soil materials: implications for environmental hazard assessment. Australian J. Soil Res., 42: 509-514. 